\title{
Interactive comment on "ENSO - cave dripwater hydrochemical relationship: a 7-year dataset from SE Australia" by C. V. Tadros et al.
}

\section{Anonymous Referee \#1}

Received and published: 7 July 2016

Interactive comment on: "ENSO - cave dripwater hydrochemical relationship: a 7-year dataset from SE Australia" by C. V. Tadros et al.

Anonymous Referee \# 1: This manuscript presents a 7-year dripwater monitoring study from Harrie Wood Cave in SE Australia. Several dripwater parameters were monitored for seven year in a two weeks rhythm. These results were used to interpret the dripwater interactions and processes evolving the dripwater composition in the epikarst. This is linked to the outside precipitation, which is extremely influenced by the ENSO in this region. This gives the opportunity to interpret $\mathrm{Mg} / \mathrm{Ca}$ and $\mathrm{Sr} / \mathrm{Ca}$ from stalagmites of this cave in the case of ENSO variability. It is a very interesting story and a nice data set, which is a good contribution to the scientific progress. Especially, it is nice to see that now more and more long-term monitoring studies are published. Further, the manuscript is well written and structured, but there are some points were the

Printer-friendly version

Discussion paper 
manuscript should be improved. In the following I will list comments and suggestions, as well as technical improvements for the manuscript. The manuscript needs minor revisions before accepting it for publication.

Comments in chronological order: General comment: On the one hand you wrote Yarrangobilly Caves and on the other hand Harrie Woods Cave. If I understand it correct, the Harrie Woods Cave is one cave in an area with a lot of caves, which are called the Yarrangobilly Caves. This is sometimes a bit confusing in the paper. I think all your data are from Harrie Woods Cave. Therefore, I would recommend to always write Harrie Woods Cave in the manuscript and only write in the "Study site" section that this caves belong to a bigger cave region, which is called Yarrangobilly Caves. Please, also mark Harrie Woods Cave in Figure 1 instead of Yarrangobilly Caves. That makes it easier to understand for the reader.

$\mathrm{P} 1, \mathrm{~L} 24$ : Is it correct that soil $\mathrm{CO} 2$ production increases during drier periods? In some cases this occurs when there is more precipitation.

P2, L20: Please delete the "dissolution" behind "differential" and set a comma behind the second "dissolution" in that line.

P2, L21: Please set a comma behind the citation parentheses.

P3, L2: Please change "Callow et al., 2014" into "Callow et al. (2014)".

P3, L6: Please change "Markowska et al., (2015)" into "Markowska et al. (2015)".

P3, L7-8: Please clarify that these five flow regimes are identified by Markowska et al. (2015), it is at the moment not clear from this sentence.

P3, L13: Please put "New South Wales, Australia" in parentheses.

P3, L17-18: Please delete "In doing so, we identified proxies which respond to the present day ENSO variability." because this fits better to the results part.

Printer-friendly version

P3, L31: Please change ". . located centrally within the cave at a depth of $38 \mathrm{~m}$ to the

Discussion paper 
surface (Fig. 1B)." to ““... .located centrally within the cave (Fig. 1B) at a depth of $38 \mathrm{~m}$ to the surface.".

P3, L30 - P4, L3: These lines should fit better to the material part.

P4, L2: Please replace "paleoclimate records" with "paleoclimate studies".

P4, L4-15: It would be a better structure putting this paragraph and the also before mentioned sentence about the different drip sites to an one paragraph. Making 2.1 Study site and climate and 2.2 Dripsite settings.

P4, L15: Please replace "Markowska et al., 2015" with "Markowska et al. (2015)".

P4, L25: Is "median annual rainfall" correct? I think it should be the annual precipitation sum. Please check this.

P4, L31: Please delete "(Fig. 1C)" in this line, because the mean annual ET is not shown in this figure, but the monthly ET.

P5, L1: Please set a comma in front of "respectively".

P5, Table1: Why does the drip site HW3 formed when HW2 stalagmite was removed? I do not understand this please give more information. Was something broken?

P6, Figure 1B: Please find another signature for HW3. Perhaps a colour filled circle. It is not very visible and the drip sites are the important points.

P6, Figure 1C: Please replace "or" at the second y-axes with "and".

P7, L3-4: Please replace "Markowska et al., 2015" with "Markowska et al. (2015)".

P7, L9: Please replace "Climate record" with "Meteorological data".

P7, L15: Please add a comma in front of "respectively".

P7, L15: Did you measure wind speed and/or direction? Please add this information.

P8, L7: Please replace ". . exposures above the surface..." with "... exposures above 
the cave".

P8, L25: Please add "concentration behind "Ca", because this is no ratio.

P9, L1-2: Please change "... highest Mg content and the paleokarst samples (R13, R14) have the lowest $\mathrm{Mg}$ and Sr concentrations." to "... highest $\mathrm{Mg} / \mathrm{Ca}$ ratio and the paleokarst samples (R13, R14) have the lowest $\mathrm{Mg} / \mathrm{Ca}$ and $\mathrm{Sr} / \mathrm{Ca}$ ratios." , because you gave ratios in Table 2 .

P9, L3: Please add "concentration" behind "Ca", because this is no ratio.

P9-11: Please change Figure 2 and 3, because you first cited Figure 3, therefroe it should be Figure 2.

P9, L 9: Is the Cumulative Water Balance the same as the effective infiltration? Therefore, precipitation minus evapotranspiration? It is not familiar to me. Perhaps you could use another word for this like infiltration or give a bit more explanation on this.

P10-11: Please give the panels in Figure 2 and 3 some a), b), c) and so on and also cite directly the different panels. That make it easier for the reader to find the right panel in the figure.

P10, L7-8: I could only see five wetter month from November 2011 to March 2012. October 2011 is quite the driest month of 2011. Please check this and clarify it.

P10, L9: Please replace "Markowska et al., 2015" with "Markowska et al. (2015)".

P10, L16: Please give some information how the data were smoothed. (10 point, 2 point filter, smoothed from the daily data?).

$\mathrm{P} 11$ : In panel b) the bars for the rain in grey are hard to see, please take another colour. In panel c) the dots for the $\mathrm{d} 180$ of the rain water are as well hard to see. Do the PWM do not have a unit? Why do you give (wt) as a unit for $\mathrm{Mg} / \mathrm{Ca}$ and $\mathrm{Sr} / \mathrm{Ca}$ for the water samples? It is a bit confusing to me, because it is liquid. Should be volume percent? 
P12, L2: Please add "rain water" in front of d180.

P12, L 5: Please change "...these recharge only events...." to "...these recharge events...".

P13, L7: Please add a comma in front of "respectively".

P13, L4-14: Could you perhaps add the drip characteristics such as seepage flow and seasonal drip to this paragraph?

P13-14, L17-1: I do not understand this sentence. Please rephrase it.

P15, L10-11: Are not also the $\mathrm{Mg} / \mathrm{Ca}$ higher? This is not completely clear to me. Please give some more information.

P16, L5: Please replace "Sinclair et al., 2012" by "Sinclair et al. (2012).

P16, L12: 2014? You only show Mg data in Figure 3 until 2013.

Figure 5: The light grey circles are very hard to see. Please choose another colour for better visibility.

P17, L25: Please replace "Markowska et al., 2015" by "Markowska et al. (2015).

P1, L20: Please replace "composition" by "ratio".

P20, Figure 6: The indication of $a$ and $b$ in the middle picture is switched. Please correct this.

P20, L4: Do you mean infiltration with "Hydrological Effective Precipitation"? If this is the case infiltration is much handier.

P21, L9: Please replace "McDonald et al., 2004" by "McDonald et al. (2004)".

Printer-friendly version

P21, L16: Please delete the comma in front of "(2004)".

P23, L2: Is Barbora Gallagher correct? Or should it be Barbara?

Discussion paper 
Interactive comment on Hydrol. Earth Syst. Sci. Discuss., doi:10.5194/hess-2016-201, 2016.

\section{HESSD}

Interactive

comment 